\title{
INTERFACES OF REGENERATION, STRUCTURE, DIVERSITY AND USES OF SOME PLANT SPECIES IN BONGA FOREST: A RESERVOIR FOR WILD COFFEE GENE POOL
}

\author{
Ensermu Kelbessa ${ }^{1}$ and Teshome Soromessa ${ }^{2, *}$ \\ ${ }^{1}$ Department of Biology, Faculty of Science, Addis Ababa University, PO Box 3434 \\ Addis Ababa, Ethiopia. Ensermuk@bio.aau.edu.et \\ Department of Biology Education, College of Education, Addis Ababa University \\ PO Box, 1176, Addis Ababa, Ethiopia. Email: Teshomes@bio.aau.edu.et
}

\begin{abstract}
Studies on the diversity, regeneration, structure and uses of some woody species in the Bonga Forest, one of the Afromontane forests of Ethiopia were made. A $900 \mathrm{~m}^{2}(30 \mathrm{~m} \times 30 \mathrm{~m})$ quadrat was laid following the homogeneity of vegetation in order to collect vegetation data. Investigation of the seedling density and regeneration of target species has been carried out using the same quadrat size. In each of these quadrats, the numbers of all seedlings that are up to the height of $150 \mathrm{~cm}$ were recorded. Individuals attaining $150 \mathrm{~cm}$ and above in height but less than $10 \mathrm{~cm}$ in diameter at breast height (DBH) were considered as sapling and counted. DBH and height of all woody species that are above $150 \mathrm{~cm}$ high and more than $10 \mathrm{~cm}$ thick were also recorded. Interviews were conducted to collect data on various human pressures exerted on different species. A total of 243 plant species belonging to 85 families were recorded from the Bonga Forest. Of these, 66 families were angiosperms, 2 gymnosperms and 17 monilophytes (ferns). Studies on the structure and regeneration of some woody species indicated that there are species that require urgent conservation measures. Sound management and monitoring, as well as maintenance of biodiversity, cultural and economic values of the forest require conservation activities that promote sustainable uses of the forest and its products.
\end{abstract}

Key words/phrases: Bonga Forest, regeneration, structure, threat, uses

\section{INTRODUCTION}

One of the main challenges facing the forest ecosystem today is the issue of reconciling the often conflicting priorities of those who depend on them for a whole range of goods and services obtained from it. Historical document indicated that Ethiopia had experienced substantial deforestation, soil degradation and an increase in the area of bare land over the years (Logan, 1946). The need for fuel wood, arable land and grazing areas are the main causes of forest degradation, frequently leading to loss of forest cover and biodiversity, erosion, desertification and reduced water resources. Several studies focussing on forests or vegetation of specific regions in Ethiopia (Hedberg, 1957; Mooney, 1963; Gilbert, 1970; Coetzee, 1978; Friis et al., 1982; Zerihun Woldu, 1985; Sebsebe Demissew, 1988; Uhlig, 1988; Zerihun Woldu et al., 1989; Uhlig and Uhlig, 1990; Zerihun Woldu and Backeus, 1991; Haugen, 1992; Mesfin Tadesse, 1992; Miehe and Miehe, 1994; Menassie Gashaw and Masresha Fetene, 1996; Demel Teketay, 2000; Fayera Senbeta and Demel Teketay, 2003; Kumelachew Yeshitela and Taye
Bekele, 2003; Teshome Soromessa et al., 2004) have been carried out. Moreover, the vegetation resources of Ethiopia, including forests, woodlands and bush lands, have been studied by several scholars (Woldemichael Kelecha, 1979; Logan, 1946; Pichi-Sermolli, 1957; von Breitenbach, 1961, 1963; Westphal, 1975; Chaffey, 1979; White, 1983; Tewolde Berhan Gebre Egziabher, 1986, 1988; Friis, 1986, 1992; Friis and Mesfin Tadesse, 1990; EFAP, 1994) who have employed different methods of vegetation classification. Almost all the aforementioned studies have made a pencil note about the intractable loss of this natural resource.

In Ethiopia at the moment, there is a growing realisation of the severity of resource degradation both by the public and the government. The various international initiatives and treaties have enhanced government awareness of the problems of natural resource degradation. In line with the realisation of forest degradation, the government of Ethiopia supported the development of National Conservation Strategy (NCS) leading to the development of first sectoral development action program for the Ethiopian Forests (EFAP, 1994). Despite, such commitment and awareness, not

\footnotetext{
* Author to whom all correspondence should be addressed.
} 
enough is being done to avert the situation, and there remains a wide gap at government level between problem awareness and the action to combat the problem. It is, therefore, imperative and urgent to study the biodiversity, ecological status and regeneration potentials of the various forests in general and that of Bonga in particular so as to device management systems thereby mitigating this alarming situation. In view of the aforementioned points, the present study aims at assessing the status, regeneration and diversity of woody species in Bonga Forest, Southwest Ethiopia.

\section{MATERIALS AND METHODS}

\section{Study site}

Bonga Forest is located about $430 \mathrm{~km}$ south-west of Addis Ababa, surrounding the Bonga town and found in what is known as the southern part of the north-western plateaux of the country. It is found in the Kaffa zone of the Southern Nations Nationalities and People's Regional State (see Fig. 1).

Bonga Forest area covers about 161,424 ha that includes forestland, settlement areas, grazing land and agricultural land. Lying within $07^{0} 00^{\prime}-7^{0} 25^{\prime} \mathrm{N}$ latitude and $35^{0} 55^{\prime}-36^{0} 37^{\prime}$ E longitude, it stretches across the boundaries of five districts (Gimbo, Menjiwo, Tello, Decha and Chena). With the intractable interference of human beings to the forest, it is more likely that the forest cover might have dwindled further down than the original cover mentioned above. The altitude of the area ranges from 1000 to $3350 \mathrm{~m}$ a.s.l. consisting of a highly dissected plateau, with flat to moderately undulating terrain on areas above $1500 \mathrm{~m}$ a.s.l. The inhabitants of the area are the Kaffa though some settlers are living in the towns near the forests mainly who have come from different parts of the country either in search of daily jobs or better arable lands. According to Daniel Gamachu (1977), Bonga is a place experiencing eight rainy months which extends from March through October with even distribution of rainfall throughout. Information on the geology of the study site could be obtained from Logan (1946) and Mohr (1971). With regard to soil, a generalised account on the nature and management of Ethiopian soils is given in Mesfin Abebe (1998). Furthermore, additional descriptions and survey of Ethiopian soils are given by Logan (1946), Murphy (1958), Westphal (1975) and EMA (1988). Based on the aforementioned works, it can be said that the major soil types around Bonga are Fluvisols and Alfisols.

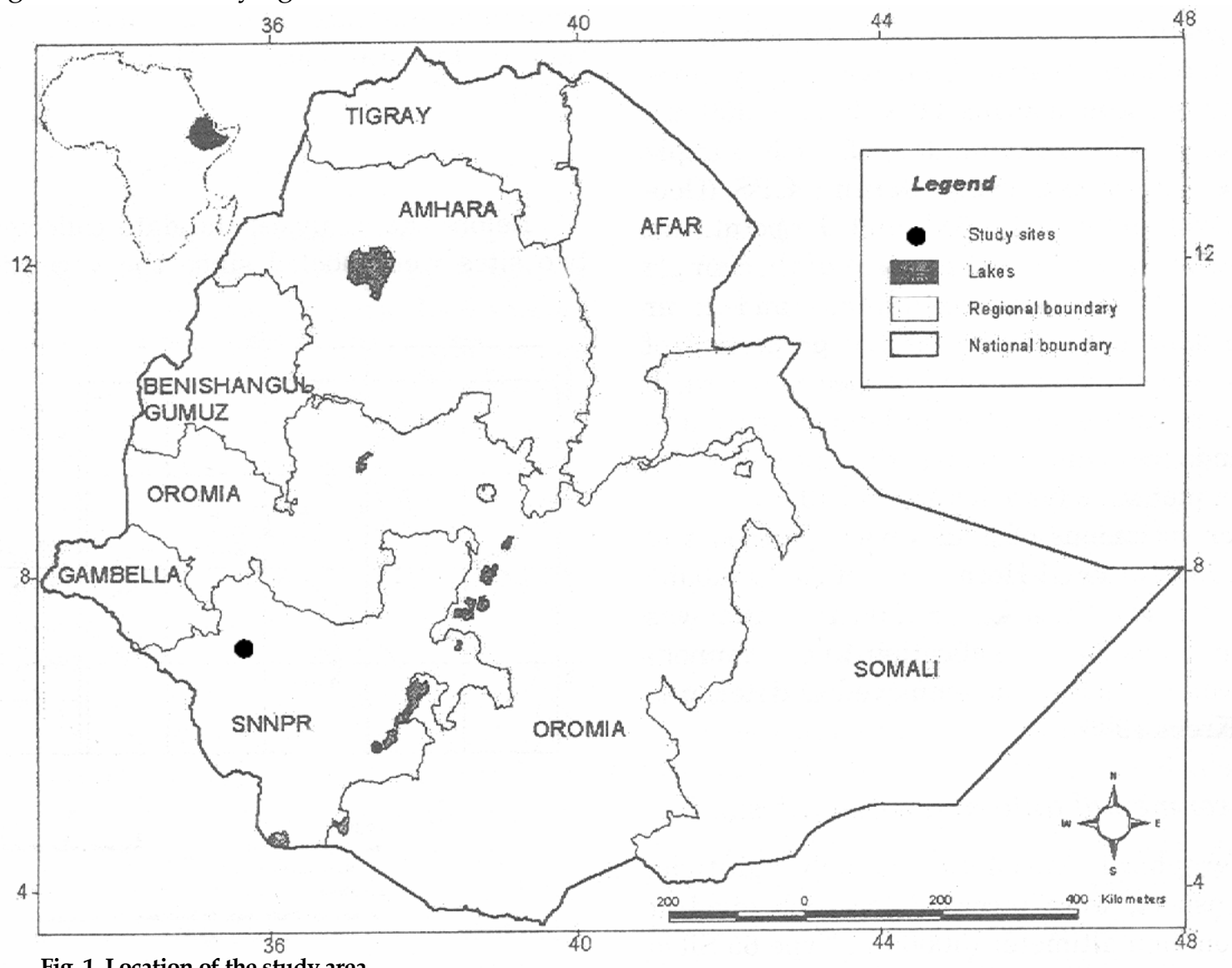

Fig. 1. Location of the study area. 


\section{Vegetation data}

The study was conducted in 2004/05. In order to collect vegetation data from the study area, 67 sample plots of a $900 \mathrm{~m}^{2}(30 \mathrm{~m} \times 30 \mathrm{~m})$ quadrat was laid following the homogeneity of vegetation. Sample plots were selected through preferential means in such a way that the various conditions encountered represented in the study forest. Woody species were counted and additional tree and shrub species within $10 \mathrm{~m}$ distance from the sample plot boundaries were recorded as present. Diameter at Breast Height (DBH) and height of all woody species that are above $150 \mathrm{~cm}$ high and more than $10 \mathrm{~cm}$ thick were recorded. DBH was measured using a meter tape and height of individuals was measured using Clinometer.

Investigation of the seedling density and regeneration of target species has been carried out using the same quadrat size. Partitions of the major quadrat were made into three, each at 10 meters intervals, within the big quadrat so as to make seedling counts easier. In each of these quadrats, the numbers of all seedlings that are up to the height of $150 \mathrm{~cm}$ were recorded. Individuals attaining $150 \mathrm{~cm}$ and above in height but less than $10 \mathrm{~cm}$ thick were considered as sapling and counted. Elders were interviewed to collected data on various human pressures exerted on different species and plant uses. Repeated field interviews procedures (Maundu, 1995); Kamatenesi-Mugisha et al., 2000; Kakudidi et al., 2000) were followed in this study. Information on vernacular names and the various uses of species were gathered from the informants via repeated field interviews as described in Maundu (1995); Kamatenesi-Mugisha et al. (2000) and Kakudidi et al. (2000). Plant specimens were identified at the National Herbarium of Ethiopia, Department of Biology, Addis Ababa University and in the field. Standard herbarium vouchers were deposited at the same Herbarium. Nomenclature of plant taxa follows different volumes of the Flora of Ethiopia and Flora of Ethiopia and Eritrea.

\section{Data analysis}

The vegetation data gathered from the field were analysed by programs embedded in Microsoft Excel. The vertical structure of the forests was described following the classification scheme International Union for Forestry Research Organisation (IUFRO) (Lamprecht, 1989). This scheme categorises a vertical structure of vegetation into upper, middle and lower storeys. The population structures of some selected species were analysed for the interpretation of the pattern of population dynamics in the forest.

\section{RESULTS AND DISCUSSION}

\section{Plant species richness of Bonga Forest}

The current study has shown that there is high plant species richness (ferns, gymnosperms and angiosperms) in Bonga Forest. A total of 243 plant species belonging to 85 families were recorded. Of these, 66 families were angiosperms, 2 gymnosperms and 17 monilophytes (ferns) - Fig. 2. A complete list of species recorded from the study site is provided in Appendix 1.

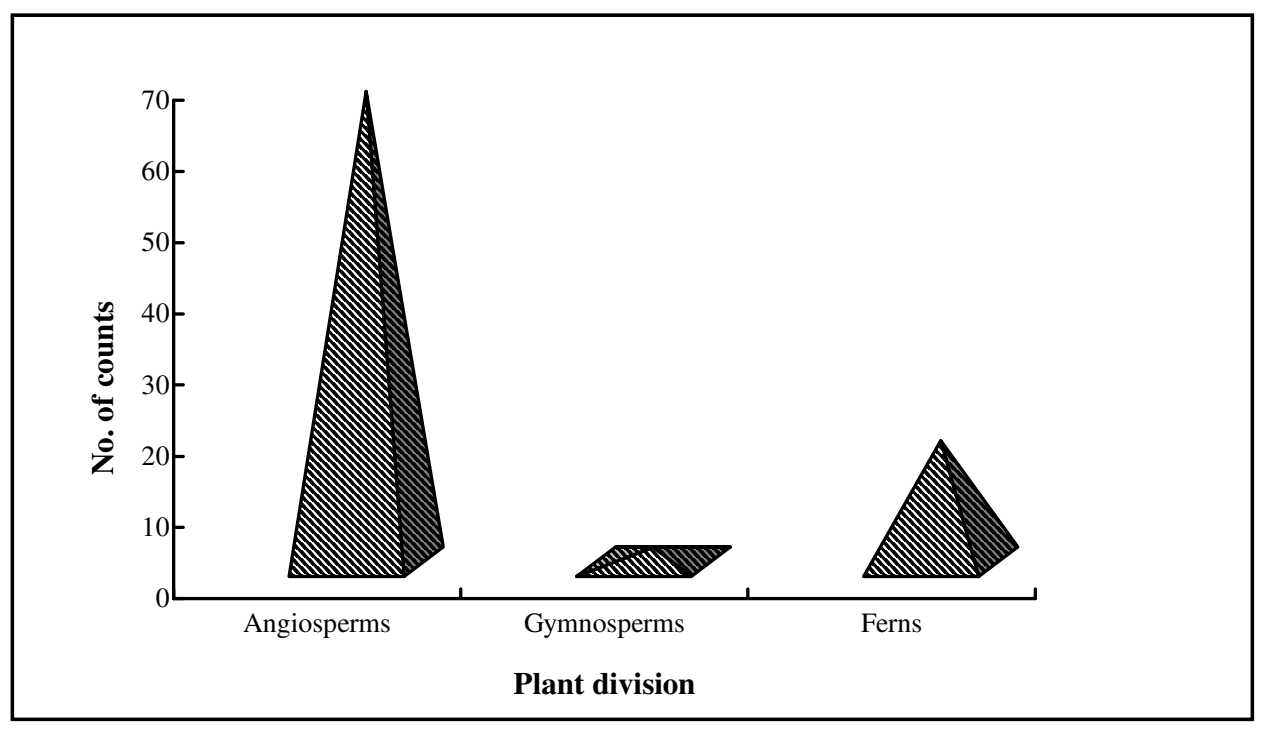

Fig. 2. Proportions of angiosperms, gymnosperms and ferns in Bonga Forest. 
Of all the families, Acanthaceae and Asteraceae are the most dominant, represented by 15 species each and making $6.17 \%$ of the total species richness. The next dominant families are Rubiaceae and Aspleniaceae which are represented by 14 species each, which is $5.76 \%$ of the total species recorded. Fabaceae is the third dominant family with $5.34 \%$ of the total species richness and followed by Lamiaceae (3.70\%). Euphorbiaceae, Moraceae and Orchidaceae are represented by 6 species each while Piperaceae and Poaceae by 5 species $(2.05 \%)$. The families Celastraceae, Lycopodiaceae, Rosaceae, Rutaceae and Verbenaceae are represented by 4 species each to make up $1.64 \%$ of the total. Aspidiaceae, Boraginaceae, Cucurbitaceae, Dracenaceae, Flacourtiaceae, Malvaceae, Meliaceae, Myrsinaceae, Oleaceae, Polygonaceae, Pteriadaceae, Ranunculaceae, Sapindaceae, Solanaceae and Urticaceae are each represented by 3 species and contributed $1.23 \%$ to the total amount of plant species in Bonga forest. The other remaining families being represented by one or two species make up $28.80 \%$ of the total species diversity.

Analysis of the habit/growth and life forms of species recorded from the Bonga Forest was performed. Fig. 3 depicts the highest proportion $(49.5 \%)$ of herbs and followed by the tree that makes up $18.8 \%$ of the total. Other life forms such as vascular epiphytes contributed the least to the total species richness.

\section{Vertical structure}

The vertical structure of the woody species occurring in the Bonga Forest was analysed using the IUFRO classification scheme as cited in (Lamprecht, 1989). The scheme classifies the storey into upper, where the tree height is greater than $2 / 3$ of the top height; middle, where the tree height is in between $1 / 3$ and $2 / 3$ of the top height and the lower storey where the tree height is less than $1 / 3$ of the top height. The top height here is considered as $45 \mathrm{~m}$. Accordingly, the emergent tree species that occupy the upper storey in Bonga Forest include Olea welwitschii, Pouteria adolfi-friederici, Prunus africana, Schefflera abyssinica and Sapium ellipticum.

The middle layer of Bonga Forest is occupied by species like Trilepisium madagascariense, Allophylus abyssinicus, Apodytes dimidiata, Ilex mitis, Polyscias fulva and Syzygium guineense. The lower storey is largely dominated by shrubs and small trees. Examples are Chionanthus mildbraedii, Vepris dainellii, Pavetta oliveriana, Dracaena afromontana, Maytenus gracilipes, Rytigynia neglecta, Coffea arabica, Teclea nobilis, Oxyanthus speciosus and Bersama abyssinica. It is important to note here that the highest proportion of species is concentrated in the lower storey followed by the middle and upper storey of the vertical structure of the forest.

\section{Density}

Density of a given species is expressed as number of stems per hectare. In the Bonga Forest, the highest density of species was recorded for Dracaena fragrans, which are 257.8 individuals per hectare. The second highest density was contributed by Psychotria orophila (173.1 individual per hectare) and this is followed by Coffea arabica that make up 172.45 individual per hectare. The least dense species in the forest are Ekebergia capensis and Cordia africana each contributing only 5.55 individual per hectare.

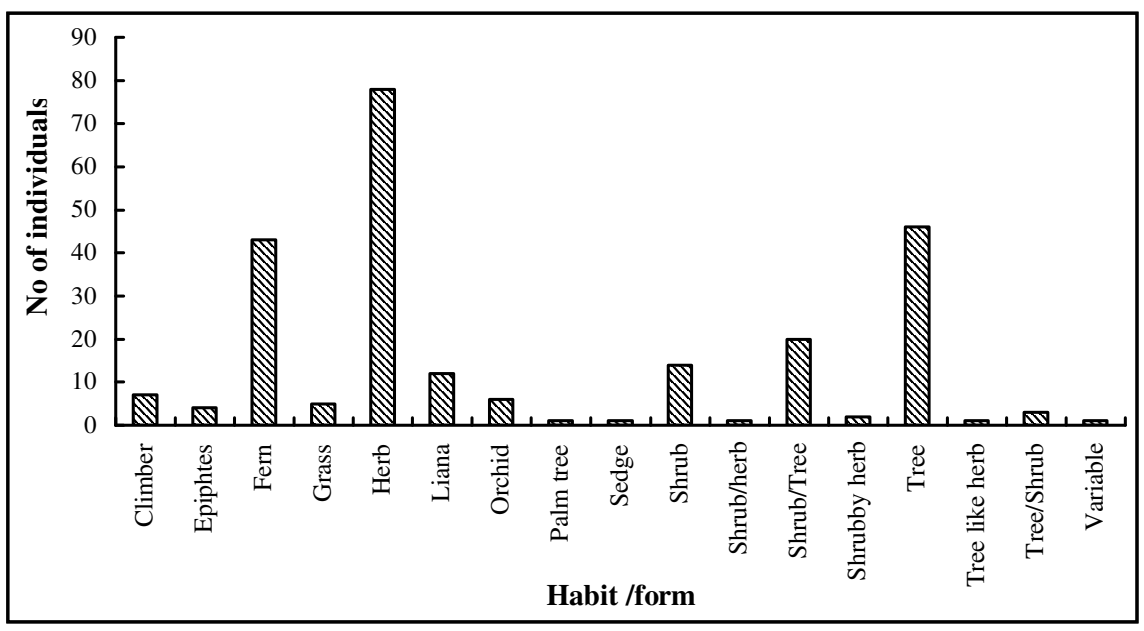

Fig. 3. Habits and or forms of species occurring in Bonga Forest. 
A comparison of the seedling and sapling density of the Forest Patches of Bonga Forest was compared (see Table 1). The same table depicts the highest seedling density for Metaba patch and the least was recorded for Agama patch. Similarly, the highest sapling density was recorded from Metaba patch and the least from Agama. However, in Forest Patches like Metaba, managing the forest for the promotion of wild coffee might have increased the figures of seedling and sapling in the area.

\section{DBH and height profile}

The frequency distribution of individuals in the various diameter and height class is not uniform. The data are summarised below (Figs 4 and 5).

As the DBH class size increases, the number of individuals gradually decrease beginning from 549 in the first class down to 32 in the fifth DBH class and showed a slight increase in the last class (Fig. 4). This appears to be a regular distribution that resembles the inverted J-shaped distribution of individuals in the different DBH classes. As seen in Fig. 4 , about $85.5 \%$ of the number of individuals was contributed by DBH classes 1, 2 and 3, indicating the predominance of small sized individuals in almost all patches of the Bonga Forest (see also Table 2). The details of DBH and Height class description of some Afromontane Forests of Ethiopia have been treated in Tamrat Bekele (1994).

Similarly, the frequency distribution of height classes of trees and shrubs in the Bonga Forest show a similar trend with the situation in the DBH class. Fig. 5 and Table 3 showed the trend in Bonga Forest and the different forest patches respectively. As seen in About $89.5 \%$ of the number of individuals was contributed by the height classes 1-5 or are below $18 \mathrm{~m}$ tall whereas the remaining $10.5 \%$ are above 18 meters (Fig. 5) suggesting the dominance of forest by low stature individuals.

Table 1. Density of seedling and saplings in the different forest patches.

\begin{tabular}{llllll}
\hline Characteristics & Obera & Wacha & Metaba & Beka & Agama \\
\hline Density of seedlings & 1463.9 & 3527.8 & 6155.6 & 5919.4 & 391.6 \\
Density of saplings & 341.6 & 1147.2 & 2663.8 & 2036.1 & 326.2 \\
\hline
\end{tabular}

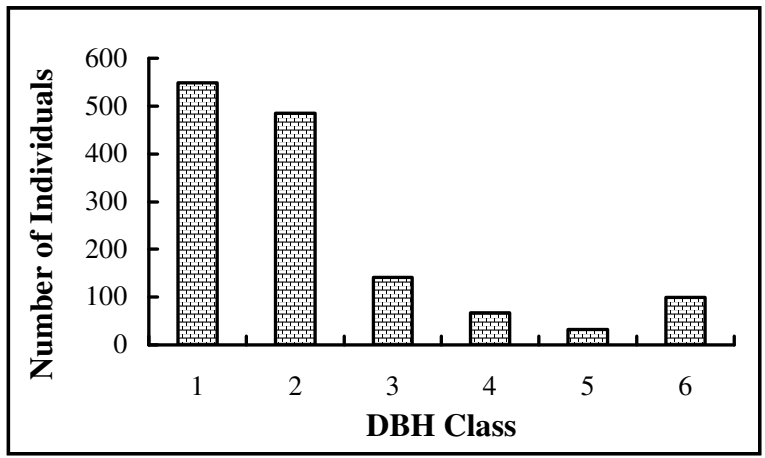

Fig. 4. DBH classes versus number of individuals in Bonga Forest. Legend: $1=10-20 \mathrm{~cm}, 2=20.1-50 \mathrm{~cm}, 3=50.1-$ $80 \mathrm{~cm}, 4=80.1-110 \mathrm{~cm}, 5=110.1-140 \mathrm{~cm}, 6=>140 \mathrm{~cm}$.)

Table 2. DBH classes and number of individuals in the different forest patches.

\begin{tabular}{llllll}
\hline DBH Class & Obera & Wacha & Metaba & Beka & Agama \\
\hline 1 & 26 & 30 & 68 & 106 & 319 \\
2 & 44 & 21 & 64 & 83 & 273 \\
3 & 12 & 13 & 14 & 23 & 79 \\
4 & 3 & 6 & 6 & 14 & 38 \\
5 & 4 & 2 & 1 & 9 & 16 \\
6 & 7 & 7 & 4 & 38 & 43 \\
\hline
\end{tabular}

Legend as in Fig. 4. 
In general, the differences observed in DBH and Height class distribution in different forest patches could be attributed to the exploitation history of these patches. These data suggest that none of the forest patches were free from exploitation. However, the extent of exploitation varies from patches to patches. For example, Obera and Wacha Forest patches are relatively exploited when compared to Agama Forest patch in Bonga Forest. The relatively more number of big and older trees in a given forest patch for example suggest that the patch has not been heavily exploited.

\section{Population structure of some species}

The population structure of 57 woody species occurring in Bonga Forest was analysed. The analysis was expressed in frequency of individuals against the already established DBH classes. The emerging population structure of the various species could be interpreted as an indication of variation in population dynamics in a given forest (Popma et al., 1988). Based on the aforementioned facts, six general patterns of population structures were recognised from the selected species of the Bonga Forest. The first pattern is formed with a species (Fig. 6a) showing a more or less even frequency distribution in all DBH classes. Such pattern is believed to have good reproduction and recruitment. Species belonging to this category include Syzygium guineense and Ilex mitis. The second pattern (Fig. 6b) is formed by a species showing a pattern where frequencies are the highest in the lower DBH classes, and then decrease toward the higher DBH classes. This pattern is exemplified by Chionanthus mildbraedii, Vepris dainellii and Oxyanthus speciosus. The third type (Fig. 6c) shows a U-shaped pattern where the frequencies are high in the lowest and highest DBH classes with more or less very low in the intermediate classes resulting in a U-shape, e.g., Polyscias fulva. This pattern vividly shows that selective cutting and removal of medium sized individuals have taken place. The fourth pattern (Fig. 6d) is a pattern where the frequencies are very low in the first classes and increase towards the higher DBH classes. Examples are Olea welwitschii, Sapium ellipticum, Schefflera abyssinica and Pavetta oliveriana. In this case, the juveniles are not well represented and it indicates poor reproduction. In species like Schefflera abyssinica and Ficus vasta, for example, the young plants prefer growth on other plants. As a result the seedlings are not seen on the ground.

Table 3. Height classes and number of individuals in different forest patches.

\begin{tabular}{llllll}
\hline Height class & Obera & Wacha & Metaba & Beka & Agama \\
\hline 1 & 41 & 38 & 61 & 155 & 377 \\
2 & 33 & 20 & 51 & 22 & 118 \\
3 & 12 & 10 & 22 & 19 & 59 \\
4 & 8 & 9 & 3 & 19 & 49 \\
5 & 3 & 3 & 6 & 21 & 81 \\
6 & 2 & 4 & 3 & 11 & 34 \\
\hline
\end{tabular}

Legend: $1=1.5-6 \mathrm{~m}, 2=6.1-9 \mathrm{~m}, 3=9.1-12 \mathrm{~m}, 4=12.1-15 \mathrm{~m}, 5=15.1-18 \mathrm{~m}, 6=18.1-21 \mathrm{~m}$.

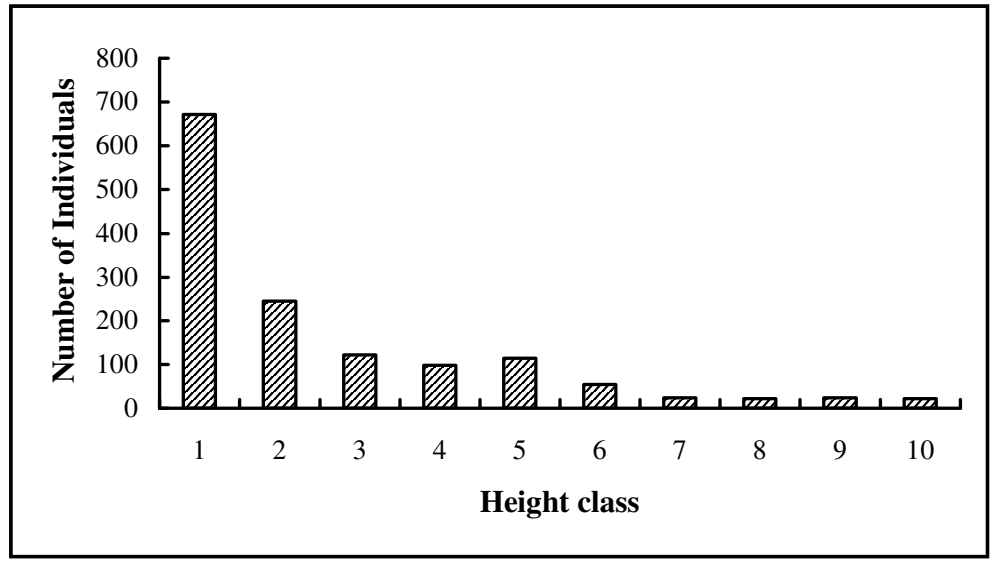

Fig. 5 Height classes versus number of individuals in Bonga Forest

Legend: $1=1.5-6 \mathrm{~m}, 2=6.1-9 \mathrm{~m}, 3=9.1-12 \mathrm{~m}, 4=12.1-15 \mathrm{~m}, 5=15.1-18 \mathrm{~m}, 6=18.1-21 \mathrm{~m}, 7=21.1-24 \mathrm{~m}, 8=24.1-27 \mathrm{~m}, 9=27.1-30 \mathrm{~m}, 10=>30 \mathrm{~m}$. 
In the fifth type (Fig. 6e) the frequencies are lower in the lowest DBH classes, followed by a gradual increase in the middle classes and then decrease in the higher DBH classes. This pattern is exemplified by Macaranga capensis, Canthium oligocarpum, Millettia ferruginea, Cassipourea malosana and Apodytes dimidiata. Such pattern indicates poor reproduction accompanied by either removal or death of the older individuals. The six pattern (Fig. 6f) is a pattern where few individuals that are represented in the second DBH and the last

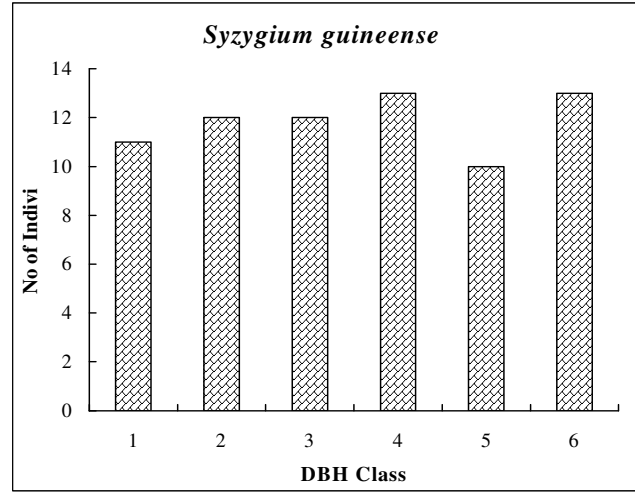

$6 a$

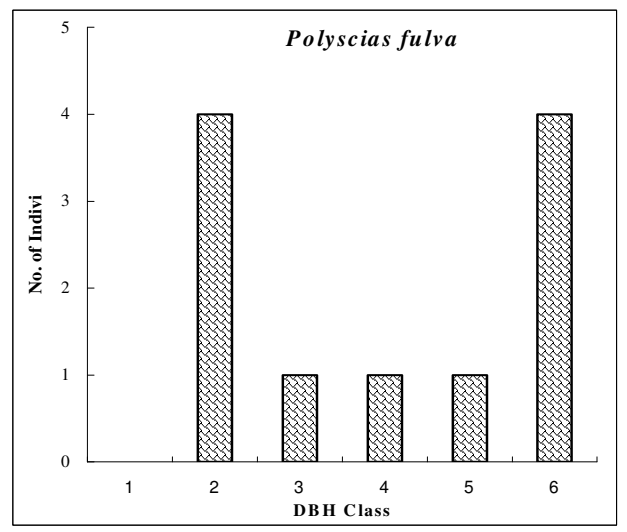

$6 c$ class, while being absent in the other classes. It might be possible to assume that such patterns may be characterised by poor reproduction, selective cutting of the medium sized individuals and poor recruitment. Only one species, Croton macrostachyus, belongs to this type. Cordia africana was absent throughout the DBH classes and only represented at the seedling stage in the forest, suggesting that the species is under high local demand.

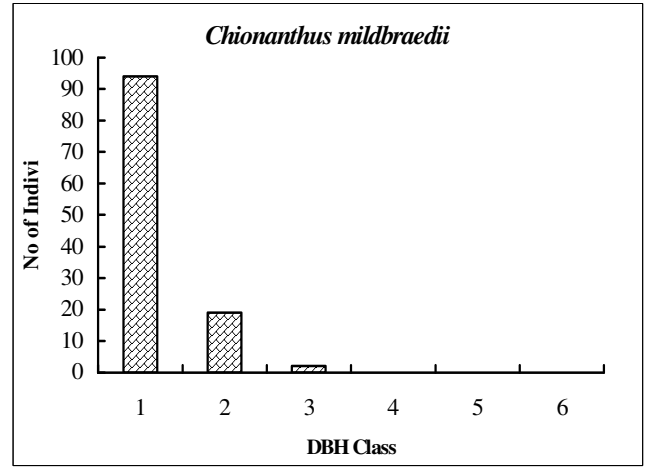

$6 b$

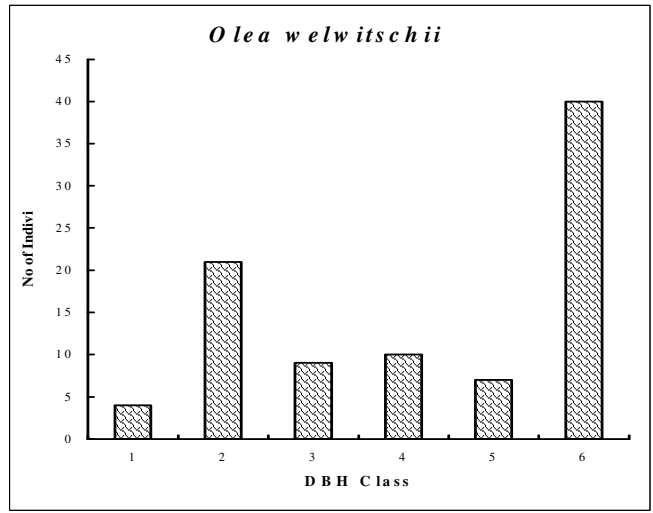

$6 \mathrm{~d}$

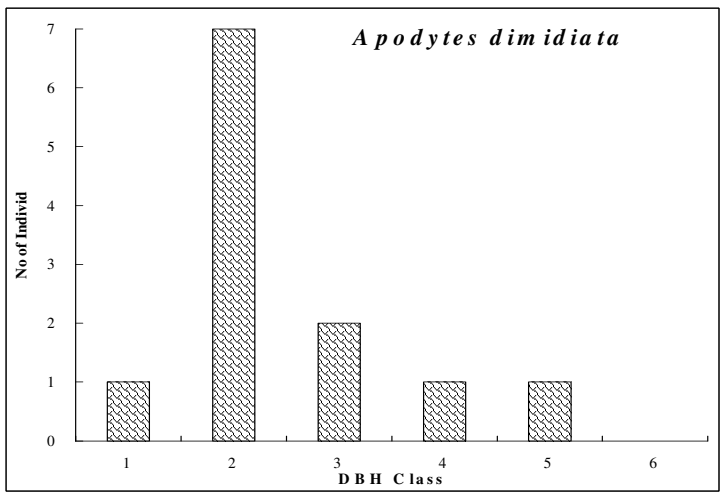

$6 e$

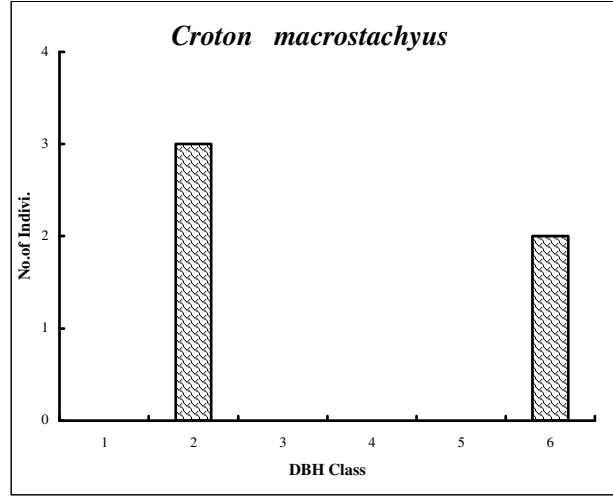

$6 f$

Fig. 6 a-f. Six representative patterns of individuals of woody species over the DBH classes in Bonga Forest, as represented by different species. 


\section{Regeneration status of some woody species}

Based on the regeneration status of the selected 57 woody species occurring in Bonga Forest, some representative figures that show the seedling, sapling and tree/shrubs status are given in Fig. 7.

Taking the seedling status into consideration, 9
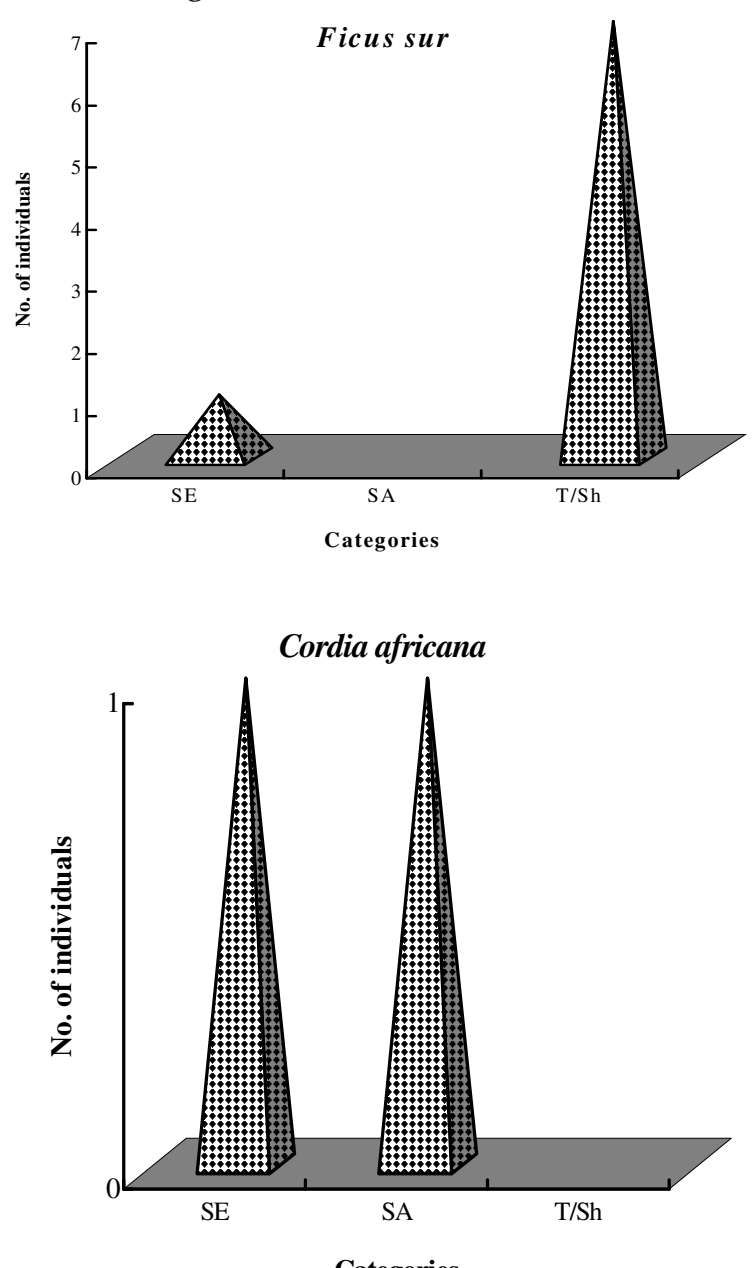

Categories

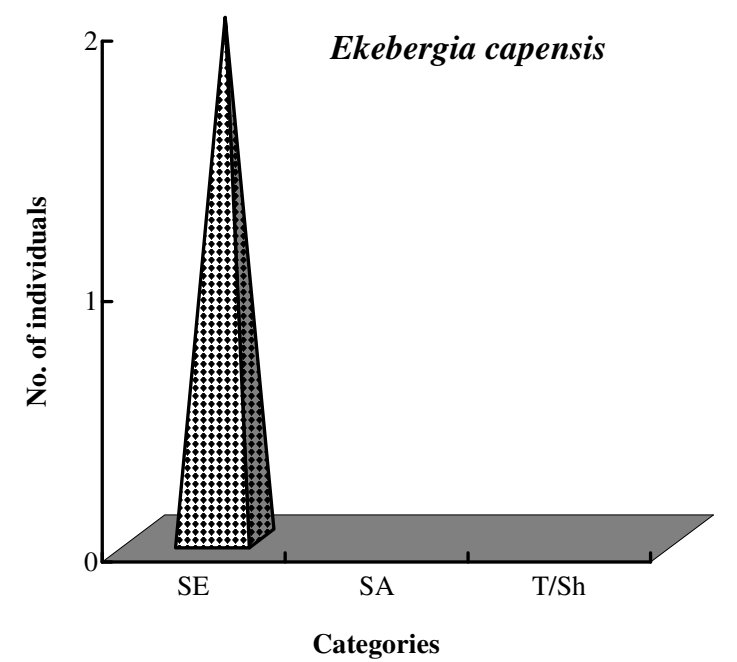

species out of the total $57(15.7 \%)$ were not represented by seedling stage. Examples are Flacourtia indica, Maesa lanceolata, Schefflera abyssinica, Sapium ellipticum, Euphorbia ampliphylla, Polyscias fulva, Ficus vasta and Buddleja polystachya..
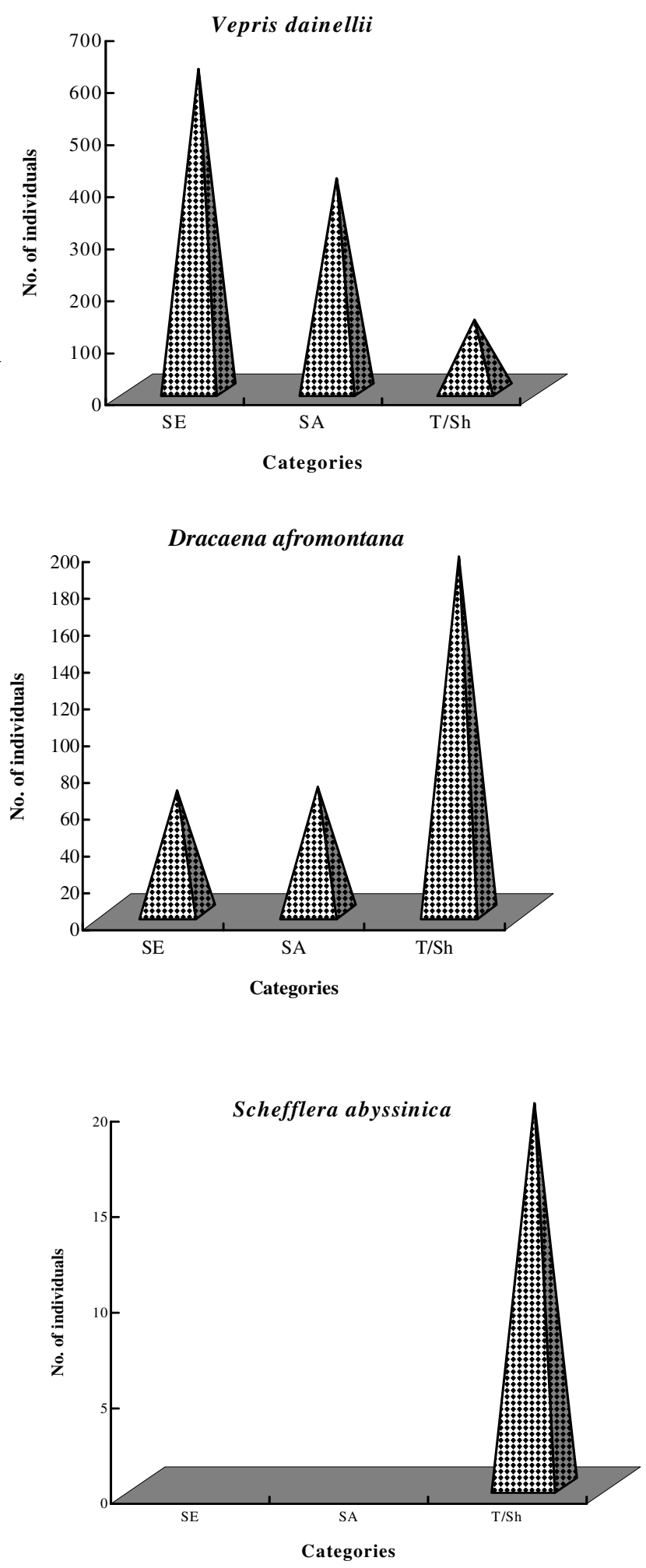

Fig. 7. Seedlings (SE), saplings (SA) and tree/shrub (T/Sh) distribution of some selected species occurring in Bonga Forest. 
On the other hand, 16 species $(28 \%)$ were not represented by their sapling stages in the Bonga Forest. Species with this pattern include Pavetta oliveriana, Ficus sur, Dracaena steudneri, Phoenix reclinata, Pouteria adolfi-friederici, Maesa lanceolata, Croton macrostachyus, Schefflera abyssinica, Pavetta abyssinica, Sapium ellipticum, Pterolobium stellatum, Ekebergia capensis, Dalbergia lactea, Polyscias fulva, Ficus vasta and Buddleja polystachya. Moreover, 6 species such as Flacourtia indica, Cordia africana, Pterolobium stellatum, Ekebergia capensis, Dalbergia lactea and Catha edulis were not represented by the tree/shrub stages in the forest. The different pattern exhibited, by some of the woody species is reproduced in Fig. 7. The pattern of species might suggest the following: (1) some species are capable of regenerating under the forest canopy (e.g., Vepris dainellii); (2) others are unable to establish in the under storey environment; (3) some seedlings and saplings are favoured by herbivores (Dracaena afromontana); (4) some species have inherent, good regeneration and good recruitment (Cassipourea malosana) capacity; (5) there are species with good regeneration capacity but have establishment problems to grow into mature tree. The highest number of seedling was recorded for Dracaena fragrans followed by Coffea arabica. The lowest number of seedlings was recorded for Cordia africana, Ficus sur and Fagaropsis angolensis, whereas the highest number of saplings was recorded for Coffea arabica followed by Dracaena fragrans. The lowest figure was that of Flacourtia indica, Cordia africana, Fagaropsis angolensis and Catha edulis. The highest tree/shrub figure was recorded for Dracaena afromontana, while the lowest figure was that of Pavetta abyssinica.

\section{Use of some selected species}

An interview on the uses of some major plant species was made so as to deduce the extent of pressure on a particular species. The interviewees have pointed out the major uses of wood products and non-wood products extracted from the forest. The use of plants by the local people can be grouped into a number of non-restrictive categories. For the purposes of simplicity, the following use categories of the plants were considered here, i.e., timber, construction, farm implements, firewood, charcoal, spices, medicinal, bee forage and for hive hanging purposes. Of the 51 species included in the interview for the use values, 47 species are used for construction purposes, 45 species as bee forage and 43 species for firewood as shown in Fig. 8. Very few species are used for spices (Aframomum cororrima and Piper capense). Many plant species fit into more than oneuse categories. For example, Allophylus abyssinicus, Olea welwitschii, Ocotea kenyensis and Cordia africana are serving six different purposes (see Table 5 for some). Others like Acanthus eminens, Aframomum corrorima, Oncoba spinosa and Cyathea manniana are used for one use category. This shows that some species are highly preferred for various uses by the local people which in one way or in the other enhances their threat.

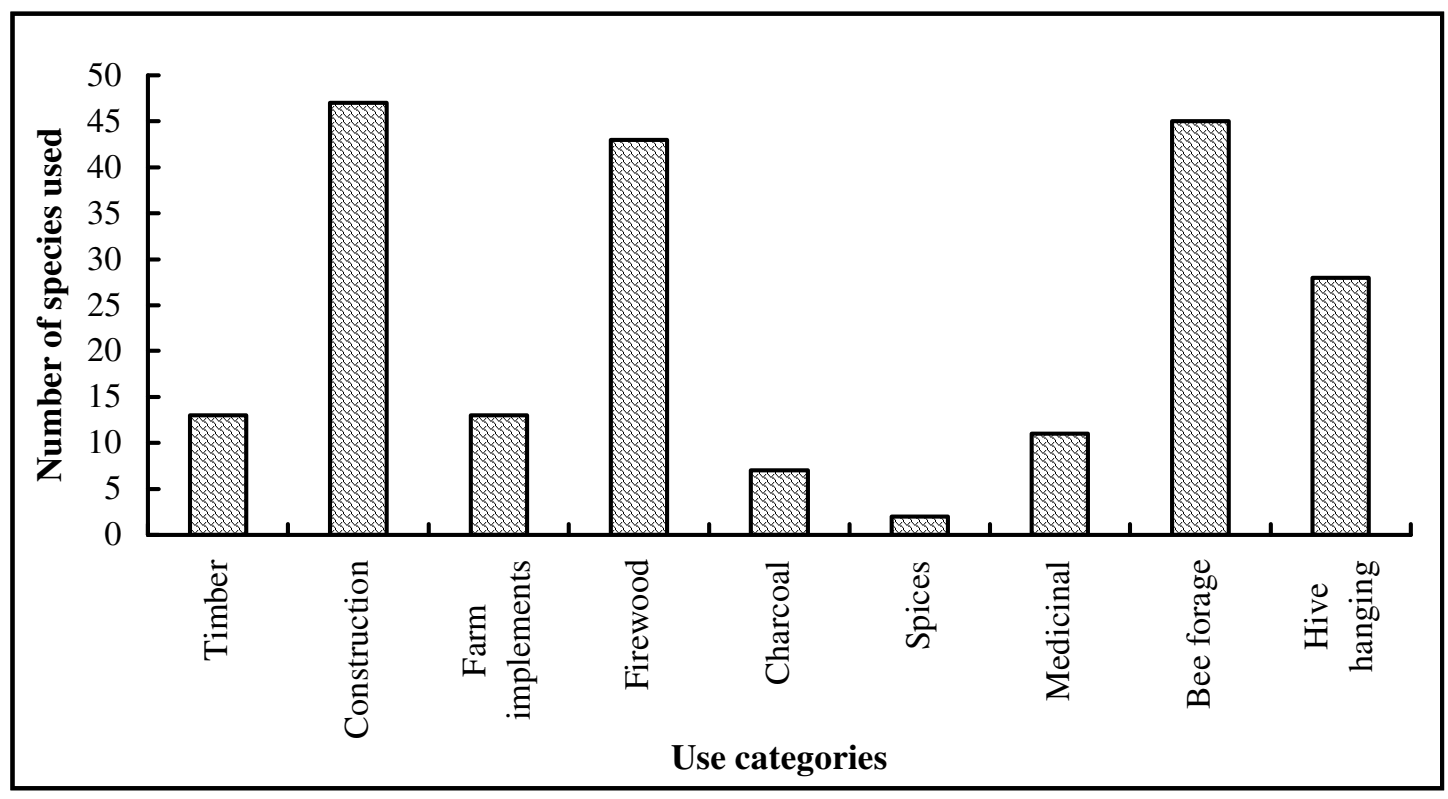

Fig. 8. Use categories and the number of species used. 


\section{Endemism}

There are a number of flowering plant species in the investigated forests that are endemic. Information on the endemic flowering plant species of Ethiopia and the levels of threat to them has been published in Ensermu Kelbessa et al. (1992), and Vivero et al. (2005). Based on the published Flora volumes and the list of species in the forest, the endemic species and the levels of threat on each taxon are given in Table 4 below. Table 4 shows that 13 endemic species have been recorded from Bonga. Based on the IUCN Criteria of level of threat, 1 species is endangered (EN) and 4 species have been evaluated as vulnerable (VU). The remaining four species have been under near threatened (NT) while five species were found to be categorized as species of least concern (LC).

\section{Status of some selected species}

Some woody species of the Bonga Forest are used for many purposes. Moreover, these species are not represented (if represented by few individual) by the various stages of development. It is then pretty clear that such species that have been over utilized and lack replacement would eventually disappear from the forest. For example, Ficus vasta and Polyscias fulva (see Table 5) are not represented by either seedling or sapling stages, showing that these species are those that need immediate conservation measures. Contrary to this fact, some species though over utilized are represented by better individuals (e.g., Vepris dainellii) at different stages. Species that are used for various purposes and yet bearing pattern I type of population structure are those that have good reproduction and recruitment (e.g., Syzygium guineense). Such species are those that don't need urgent conservation attention.

Table 4. Endemic species occurring in Bonga Forest.

\begin{tabular}{llll}
\hline No. & Scientific name & Status & Family \\
\hline 1 & Aramomum corrorima & VU & Zingiberaceae \\
2 & Brillantaisia grotanellii & VU & Acanthaceae \\
3 & Crassocephalus macropappum & LC & Asteraceae \\
3 & Crotalaria gillettii & NT & Fabaceae \\
4 & Dorstenia soerensenii & VU & Moraceae \\
5 & Eryhtrina brucei & LC & Fabaceae \\
6 & Lippia adoensis & LC & Verbenaceae \\
7 & Millettia ferruginea & LC & Fabaceae \\
8 & Pycnostacys abyssinica & NT & Lamiaceae \\
9 & Satureja paradoxa & NT & Lamiaceae \\
10 & Scadoxus nutans & EN & Amaryllidaceae \\
11 & Tiliacora troupinii & VU & Menispermaceae \\
12 & Vepris dainellii & NT & Rutaceae \\
13 & Vernonia leopoldi & LC & Asteraceae \\
\hline
\end{tabular}

Table 5. Status of some selected species of the Bonga Forest.

\begin{tabular}{llllll}
\hline Species & No. of Uses & Seedling & Sapling & Tree/Shrub & Structure \\
\hline Albizia gummifera & 5 & 22 & 13 & 3 & Pattern I \\
Allophylus abyssinicus & 6 & 15 & 8 & 3 & Pattern III \\
Apodytes dimidiata & 5 & 5 & 2 & 12 & V \\
Celtis africana & 5 & 4 & 4 & 2 & III \\
Cordia africana & 6 & 1 & 1 & - & VI \\
Croton macrostachyus & 5 & 8 & - & 3 & VI \\
Dracaena fragrans & 2 & 1800 & 514 & 7 & I \\
Ekebergia capensis & 5 & 2 & - & - & VI \\
Ficus vasta & 5 & - & - & 6 & III \\
Polyscias fulva & 5 & - & - & 8 & III \\
Pouteria adolfi-friederici & 5 & 6 & - & 13 & III \\
Prunus africana & 7 & 6 & - & 3 & VI \\
Schefflera abyssinica & 6 & - & 10 & 71 & IV \\
Syzygium guineense & 6 & 46 & 21 & 13 & I \\
Teclea nobilis & 5 & 9 & 2 & 18 & I \\
Trilepisium madagascariense & 5 & 57 & 406 & 134 & I \\
Vepris dainellii & 5 & 616 & & \\
\hline
\end{tabular}

Note that the structure of these species is the one discussed under population structure previously. 


\section{CONCLUSIONS AND RECOMMENDATIONS}

Bonga Forest is one of the remaining forests harbouring a unique gene reserve of wild coffee. This forest is ecologically, socially, economically and culturally very important for the inhabitants residing nearby who are mostly dependent on forest product to make their living. Loss of such a forest and the various threatened species would have great implications for the environment, biodiversity and socio-economic setup of the communities.

Bonga Forest harbours species that are economically and ecologically important. Yet some of these species have population structures that showed patterns with no or few individuals at lower size classes. Such species require urgent conservation measures that will enhance healthy regeneration and guarantee sustainable uses of these species. Some other economically important species of this forest were not represented in the seedling or sapling stages denoting that they are under threat. It is therefore mandatory to implement conservation measures (both in-situ and ex-situ) for such species of the forest. Specifically, to provide a better management and monitoring of the forest, the following points are forwarded as recommendations:

* Differentiate between areas of various importance - coffee planting and management of wild and semi-wild coffee should be regulated, and some forest areas should be set aside for conservation of biodiversity - both flora and fauna resources;

* Enhance the development of species that are sources of spices (Aframomum corarrima and Piper capense) which are friendly to the forest and are also means of income generation,

* Introduce modern beehives so as to reduce the pressure on selectively utilised species for the purposes of hive construction in particular, Polyscias fulva, Croton macrostachyus and Euphorbia ampliphylla,

* Assist in the propagation and the distribution of seedlings of plants whose uses are already wide spread in the area and which are threatened, e.g., Cordia africana, Olea welwitschii, Euphorbia ampliphylla, Polyscias fulva, etc.

* Enhance controlled Eucalyptus plantation for the purposes of fuel wood along road sides, on wasted lands and pastures and
* Enrichment plantation of those species that have been over utilised for various purposes such as Olea welwitschii, Pouteria adolfifreiderici, Cordia africana, Euphorbia ampliphylla and Polyscias fulva.

\section{ACKNOWLEDGEMENTS}

We are grateful to the local residents who have been helpful during the field work and who were kind enough to share their knowledge and experiences without reservations.

\section{REFERENCES}

1. Chaffey, D.R. (1979). Southwest Ethiopia Forest Inventory Project, a Reconnaissance Inventory of Forest in South-West Ethiopia. Land Resources Development Centre, Tolworth Tower Surbition Survey, England.

2. Coetzee, J.A. (1978). Phytogeogarphical aspects of the montane forests of the chain of mountains on the eastern side of Africa. Erdwiss Forschung 11:482-494.

3. Daniel Gamachu (1977). Aspects of Climate and Water Budget in Ethiopia. Addis Ababa University Press, Addis Ababa.

4. Demel Teketay (2000). Vegetation Types and Forest Fire Management in Ethiopia. In: Proceedings of the Round Table Conference on Integerated Forest Fire Management in Ethiopia, , pp 1-35. Ministry of Agriculture (MOA) and Deutsche Gesellschaft für Technische Zusammenarbeit (GTZ), Addis Ababa.

5. EFAP (1994). Ethiopian Forestry Action Program, EFAP Secretariat, Addis Ababa.

6. EMA (1988). National Atlas of Ethiopia. Ethiopian Mapping Authority (EMA), Addis Ababa.

7. Ensermu Kelbessa, Sebsebe Demissew, Zerihun Woldu and Edwards, S. (1992). Some threatened endemic plants of Ethiopia. In: Botany 2000: East and Central Africa, (Edwards, S. and Zemede Asfaw, eds). NAPERICA Monograph Series No. 2, pp. 35-55.

8. Feyera Senbeta and Demel Teketay (2003). Diversity, community types and population structure of woody plants in Kimphee Forest, a virgin natural reserve in southern Ethiopia. Ethiop. J. Biol. Sci. 2(2):169-187.

9. Friis, I. (1986). The forest Vegetation of Ethiopia. Symb. Bot. Upsa. 26(2):31-47.

10. Friis, I. (1992). Forest and forest trees of north-east Tropical Africa. Kew Bull. Additional Series 15:1-396.

11. Friis, I., and Mesfin Tadesse (1990). The evergreen forests of tropical north-east Africa. Mitt. Inst. Allg. Bot. Hamburg. 23a:249-263.

12. Friis, I., Rasmussen, F.N and Vollesen, K. (1982). Studies in the flora and vegetation of southwest Ethiopia. Opera Botanica 63:8-70. 
13. Gilbert, E.F. (1970). Mount Wachacha: A botanical Commentary. Walia 2:3-12.

14. Haugen, T. (1992). Woody vegetation of Borana, south Ethiopia, a study on the main vegetation types of the area. SINET: Ethiop. J. Sci. 15:117130.

15. Hedberg, O. (1957). Afroalpine vascular plants, a taxonomic revision. Symb. Bot. Upsa.15 (1):1411.

16. Kakudidi, E.K., Bukenya-Ziraba, R. and Kasenene, J.M. (2000). The medicinal plants in and around Kibale National Parks in western Uganda. Lidia 5:109-124.

17. Kamatenesi-Mugisha, M., Hoft, R. and BukenyaZiraba, R. (2000). Ethnobotanical use of Rytgynia (nyakibazi) in Bwindi Impenetrable National Park, s-W Uganda. Lidia 5:97-108.

18. Kumelachew Yeshitela and Taye Bekele (2003). The woody species composition and structure of Masha-Anderacha Forest, south-western Ethiopia. Ethiop. J. Biol. Sci. 2(1):31-48.

19. Lamprecht, H. (1989). Silviculture in Tropics. Tropical Forest Ecosystems and their Tree SpeciesPossibilities and Methods for their Long Term Utilization. TZ-Verlagsgesellschaft $\mathrm{GmbH}$, Rossdort, Germany.

20. Logan, W.E.M. (1946). An Introduction to the forests of central and southern Ethiopia. Imperial Forest Institute, University of Oxford. Inst. Paper, No. 24, 58 pp.

21. Maundu, P.M. (1995). Methodology of collecting and sharing indigenous knowledge: Case study. Indig. Know. Dev. Mon. 3:3-5.

22. Menassie Gashaw and Masresha Fetene (1996). Plant communities of the afroalpine vegetation of the Sanetti Plateau, Bale Mountains, Ethiopia. SINET: Ethiop. J. Sci. 19:65-86.

23. Miehe, G. and Miehe, S. (1994). Ericaceous Forests and Heath Lands in the Bale Mountains of South Ethiopia: Ecology and Man's Impact. Stiftung Walderhaltung in Africa, Hamburg.

24. Mesfin Abebe (1998). Nature and Management of Ethiopian Soils. Alemaya University of Agriculture. Ethiopia.

25. Mesfin Tadesse (1992). A survey of the evergreen forests of Ethiopia. NAPRECA Monograph Series No. 2, pp. 1-18.

26. Mohr, P.A. (1971). The Geology of Ethiopia. University College of Addis Ababa, Central Printing Press, Addis Ababa.

27. Mooney, H.F. (1963). An account of two journeys to the Araenna Mountains in Bale Province (south-east Ethiopia), 1958 and 1959-1960. Proceedings of the Linnaean Society 172:127-147.

28. Murphy, H.P. (1958). The Fertility Status of some Soils of Ethiopia. College of Agriculture, Jimma, Ethiopia.

29. Pichi-Sermolli, R.E.G. (1957). Una carta geobotanica dell' Africa Orientale (Eritrea, Etiopia, Somalia). Webbia 13:15-132.

30. Popma, J., Bongers, F. and Meave del Castillo, J. (1988). Patterns in the vertical structure of the lowland rain forest of Los Tuxtlas, Mexico. Vegetatio 74:81-91.

31. Sebsebe Demissew (1988). The Floristic composition of the Menagesha State Forest and the need to conserve such forest in Ethiopia. Mountain Research and Development 8:243-247.

32. Tamrat Bekele (1994). Phytosociology and ecology of a humid afromontane forest on the central plateau of Ethiopia. J. Veg. Sci. 5:87-98.

33. Teshome Soromessa, Demel Teketay and Sebsebe Demissew (2004). Ecological study of the vegetation in Gamo Gofa zone, southern Ethiopia. Tropical Ecology 45 (2):209-221.

34. Tewolde Berhan Gebre Egziabher (1986). Ethiopian vegetation - past, present and future. SINET: Ethiop. J. Sci. 9:1-13.

35. Tewolde Berhan Gebre Egziabher (1988). Vegetation and environment of the mountains of Ethiopia: implications for utilisation and conservation. Mountain Research and Development 8:211-216.

36. Uhlig, S.K. (1988). Mountain forests and upper tree limit on the south-eastern plateau of Ethiopia. Mountain Research and Development 8:227-234.

37. Uhlig, S.K. and Uhlig, K. (1990). The floristic composition of a natural montane forest in south-eastern Ethiopia. Feddes Repert. 101:227234.

38. Vivero, J.L., Ensermu Kelbessa and Sebsebe Demissew (2005). The red list of endemic flowering plants of Ethiopia and Eritrea. Fauna \& Flora International, Cambridge, UK.

39. von Breitenbach, G. (1961). Forests and woodlands of Ethiopia, a geobotanical contribution to the knowledge of the principal plant communities of Ethiopia, with special regards to forestry. Ethiopian Forestry Review 1:5-16.

40. von Breitenbach, G. (1963). Indigenous Trees of Ethiopia. Ethiopian Forestry Association, Addis Ababa.

41. Westphal, E. (1975). Agricultural Systems in Ethiopia. Centre for Agricultural Publishing and Documentation, Wageningen.

42. White, F. (1983). The vegetation of Africa. A Descriptive Memoir to accompany the UNESCO/AETFAT/UNSO vegetation map of Africa. Natural Resources Research (Paris) 20:1356.

43. Woldemichael Kelecha (1979). Compiled Reports on Ethiopian Forest, Original by Russ, G.W. (1945). Addis Ababa, Ethiopia.

44. Zerihun Woldu (1985). Variation in Grassland Vegetation on the Central Plateau of Shewa, Ethiopia, in Relation to Edaphic Factors and Grazing Conditions. Doctoral Thesis, Uppsala University, Uppsala.

45. Zerihun Woldu and Backeus, I. (1991). The shrub land vegetation in western Shewa, Ethiopia and its possible recovery. J. Veg. Sci. 2:173-180.

46. Zerihun Woldu, Feoli, E. and Lisanework Nigatu (1989). Partitioning an elevation gradient of vegetation from south-eastern Ethiopia by probability methods. Vegetation 18:189-198. 
Appendix 1. Plant species recorded from the study site with their corresponding families.

\begin{tabular}{|c|c|c|c|}
\hline Species & Family & Species & Family \\
\hline Acanthus eminens C.B.Clarke & Acanthaceae & $\begin{array}{l}\text { Isoglossa punctata (Vahl) Brummitt \& } \\
\text { Wood }\end{array}$ & Acanthaceae \\
\hline Achyranthes aspera L. & Amaranthaceae & Isoglossa somalensis Lindau & Acanthaceae \\
\hline Acmella caulirhiza Del. & Asteraceae & Jasminum abyssinicum DC. & Oleaceae \\
\hline Aerangis brachycarpa (Rich) Reichb.f. & Orchidaceae & Juniperus procera Endl. & Cupressaceae \\
\hline Aeschynomene abyssinica Vatke & Fabaceae & $\begin{array}{l}\text { Justicia diclipteroides Lindau subsp. } \\
\text { aethiopica Hedre' } n\end{array}$ & Acanthaceae \\
\hline Aframomum corrorima (Braun) Jansen & Zingiberaceae & Justicia schimperiana T. Anders & Acanthaceae \\
\hline Afrolepis monocarpa (Cordem.) C. Chr. & Arthropteridaceae & Laggera alata Sch. Bip.ex Oliv. & Asteraceae \\
\hline Afrolepis undulata J. Smith & Arthropteridaceae & Landolphia buchananii Stapf. & Apocyanaceae \\
\hline Ageratum conyzoides $\mathrm{L}$. & Asteraceae & Lantana trifolia $\mathrm{L}$. & Verbenaceae \\
\hline Agrocharis incognita Heywood \& Jury & Apiaceae & Lepidotrichilia volkensii (Gurke) Leory & Meliaceae \\
\hline Ajuga sp. & Lamiaceae & Leucas calostachys Oliv. & Lamiaceae \\
\hline Albizia gummifera (Gmel.) C.A. Sm. & Fabaceae & Lippia adoensis Hochst. ex Walp. & Verbenaceae \\
\hline Alchemilla fischeri Engl. & Rosaceae & Lycopodium cernuum L. & Lycopodiaceae \\
\hline Allophyllus abyssinicus (Hochst.) Radlk & Sapindaceae & Lycopodium clavatum L. & Lycopodiaceae \\
\hline Amorphophllus gallaensis (Engl.) N.E.Br. & Araceae & Lycopodium dacrydioides Bak. & Lycopodiaceae \\
\hline Anthrophyum mannianum Hook. & Vittariaceae & Lycopodium verticillatum (Kunzte) A. Br. & Lycopodiaceae \\
\hline Apodytes dimidiata E. Mey. ex Arn & Icaccinaceae & Macaranga capensis (Baill.) Sim & Euphorbiaceae \\
\hline Arthropteris monocarpa (Cordem.) C.Chr. & Oleandraceae & Maesa lanceolata Forssk. & Myrsinaceae \\
\hline Asparagus africanus Lam. & Asparagaceae & Maytenus arbutifolia (A. Rich.) Wilczek & Celastraceae \\
\hline Asplenium anisophyllum Kunze & Aspleniaceae & Maytenus gracilipes (Welw.ex Oliv.) Exell & Celastraceae \\
\hline Asplenium boltonii Hook. ex Schelpe & Aspleniaceae & Metarungia pubinervia (T. Anders) Baden & Acanthaceae \\
\hline Asplenium bugoiense Hieron & Aspleniaceae & Microlepia speluncae (L.) S. Moore & Dennstaedtiaceae \\
\hline Asplenium cei Pich-Serm. & Aspleniaceae & Millettia ferruginea (Hochst.) Baker & Fabaceae \\
\hline Asplenium erectum Willd. & Aspleniaceae & Mimulopsis solmsii Schweinf. & Acanthaceae \\
\hline Asplenium friesiorum C.Chr. & Aspleniaceae & Monopsis stellarioides (Presl.) Urban & Lobeliaceae \\
\hline Asplenium hypomelas Kuhn & Aspleniaceae & Myrsine africana $\mathrm{L}$. & Myrsinaceae \\
\hline Asplenium linkii Kuhn & Aspleniaceae & Ocimum lamiifolium Hochst ex. Bent. & Lamiaceae \\
\hline Asplenium lunulatum SW & Aspleniaceae & Ocotea kenyensis (Chiov.) Robyns \& Wilcz & Lauraceae \\
\hline Asplenium mannii Hook. & Aspleniaceae & Oldenlandia lancifolia (K. Schum.) DC. & Rubiaceae \\
\hline Asplenium orientalis (G.F. Gmel.) Posth. & Aspleniaceae & Olea welwitschii (Knobl.) Gilg \& Schellenb. & Oleaceae \\
\hline Asplenium sandersonii Hook. & Aspleniaceae & Oleandra distenta Kunze & Oleandraceae \\
\hline Asplenium suppositum Hieron & Aspleniaceae & Olyra latifolia L. & Poaceae \\
\hline Asplenium theciferum (HBK) Mett & Aspleniaceae & Oncoba routledgei Sprague & Flacourtiaceae \\
\hline Athyrium scandicinum (Willd.) C. Persl. & Athyriaceae & Oncoba spinosa Forssk. & Flacourtiaceae \\
\hline Basella alba $\mathrm{L}$. & Basellaceae & Oplismenus hirtellus (L.) P. Beauv. & Poaceae \\
\hline Begonia wallastonii Bak. & Begoniaceae & Oxalis corniculata $\mathrm{L}$. & Oxalidaceae \\
\hline Bersama abyssinica Fresen. & Melianthaceae & Oxyanthus speciosus DC. & Rubiaceae \\
\hline Bidens pilosa $\mathrm{L}$. & Asteraceae & Paullinia pinnata L. & Sapindaceae \\
\hline Brillantaisia grotanellii Pichi-Serm. & Acanthaceae & Pavetta abyssinica Fresen. & Rubiaceae \\
\hline Brillantaisia madagascariensis T. Anders. & Acanthaceae & Pavetta oliveriana Hiern & Rubiaceae \\
\hline Brucea antidysenterica J. F. Mill & Simaroubaceae & Pentas lanceolata (Forssk.) Defl. & Rubiaceae \\
\hline Buddleja polystachya Fresen. & Loganiaceae & Peperomia abyssinica Miq. & Piperaceae \\
\hline Canthium oligocarpum Hiern & Rubiaceae & Peperomia molleri C. DC. & Piperaceae \\
\hline Carduus leptacanthus Fresen. & Asteraceae & Peperomia retusa (L.f.) A. Dietr. & Piperaceae \\
\hline Carex chlorosaccus C.B. Clarke & Cyperaceae & Peperomia tetraphylla (Forst.) Hook. \& Arn & Piperaceae \\
\hline Cassipourea malosana (Baker) Alston & Rhizophoraceae & Peponium vogelii (Hook.f.) Engl. & Cucurbitaceae \\
\hline Catha edulis (Vahl) Forssk. ex Endl. & Celastraceae & Persicaria salicifolia Willd. & Polygonaceae \\
\hline Celtis africana Burm. $\mathrm{f}$ & Ulmaceae & Persicaria setosula (A. Rich.) K.L. Wilson & Polygonaceae \\
\hline Cheirostylis lepida (Reichb.f.) Dalfe & Orchidaceae & Phaulopsis imbricata (Forssk.) Sweet & Acanthaceae \\
\hline Chionanthus mildbraedii Stearn & Oleaceae & Phoenix reclinata Jacq. & Palmae \\
\hline Clausena anisata (Wild.) Benth. & Rutaceae & Physalis peruviana $\mathrm{L}$. & Solanaceae \\
\hline Clematis simensis Fresen. & Ranunculaceae & Pilea bambusetii C.A.Sm. & Urticaceae \\
\hline Clerodendrum myricoides Vatke & Verbenaceae & Pilea rivularis Wedd. & Urticaceae \\
\hline Coffea arabica L. & Rubiaceae & Piper capense L.f. & Piperaceae \\
\hline Combretum paniculatum Vent. & Combreataceae & Pittosporum viridiflorum Sims & Pittosporaceae \\
\hline Commelina diffusa Burm.f. & Commelinaceae & Plantago palmata Hook.f. & Plantaginaceae \\
\hline Coniogramme africana Hieron & Hemionitidaceae & Plectrantus assurgens (Bak.) Morton & Lamiaceae \\
\hline Conyza agrostophylla F.G. Davies & Asteraceae & Plectrantus sylvestris Guerke & Lamiaceae \\
\hline Cordia africana Lam. & Boraginaceae & Polyscias fulva (Hiern) Harms & Araliaceae \\
\hline Crassocephalum crepidioides S. Moore & Asteraceae & Polystachya bennettiana Reichb.f. & Orchidaceae \\
\hline Crassocephalum macropappum S. Moore & Asteraceae & Polystachya cultriformis (Thon.) Sprengel & Orchidaceae \\
\hline Crotalaria gillettii Polhill & Fabaceae & Polystachya lindblomii Schltr. & Orchidaceae \\
\hline
\end{tabular}




\begin{tabular}{|c|c|c|c|}
\hline Species & Family & Species & Family \\
\hline Crotallaria brevidens Benth. & Fabaceae & Polystichum transvaalense N.C. Anthony & Aspidaceae \\
\hline Croton macrostachyus Del. & Euphorbiaceae & Pouteria adolfi-friederici (Engl.) Baehni & Sapotaceae \\
\hline Culcasia falcifolia Engl. & Araceae & Premna schimperi Engl. & Verbenaceae \\
\hline Cupressus lusitanica Mill. & Cupressaceae & Prunus africana (Hook.f.) Kalkam & Rosaceae \\
\hline Cyathea manniana Hook. & Cyatheaceae & Psychotria orophila Petit & Rubiaceae \\
\hline Cynoglossum amplifolium DC. & Boraginaceae & Pteridium aquilinum (L.) Kuhn & Dennstaedtiaceae \\
\hline Dalbergia lactea Vatke & Fabaceae & Pteris dentata Forssk. & Pteriadaceae \\
\hline Deinbollia kilimandscharica Taub. & Sapindaceae & Pteris pteridioides (Hook.) Ballard & Pteriadaceae \\
\hline Desmodium repandum Vahl & Fabaceae & Pteris quadriaurita Retz. & Pteriadaceae \\
\hline Diaphananthe adoxa Rasm. & Orchidaceae & Pterolobium stellatum Brenan & Fabaceae \\
\hline Dichondra repens J.R. \& G. Forst. & Convolvulaceae & Pycnostachys abyssinica Fresen. & Lamiaceae \\
\hline Dichrocephala integrifolia O. Kuntze & Asteraceae & Ranunculus multifidus Forssk. & Ranunculaceae \\
\hline Dicliptera laxata C.B. Clarke & Acanthaceae & Rhamnus prinoides L'Herit. & Rhamnaceae \\
\hline Dicranopteris linearis (Burm.f.) Underw. & Gleicheniaceae & Ricinus communis L. & Euphorbiaceae \\
\hline Didymochlaena truncatula J. Sm & Aspidiaceae & Rothmannia urcelliformis (Hiern) Robyns & Rubiaceae \\
\hline Diospyros abyssinica F. White & Ebenaceae & Rubus apetalus Poir. & Rosaceae \\
\hline Dissotis senegambiensis Triana & Melastomataceae & Rubus steudneri Schweinf. & Rosaceae \\
\hline Dolichos sericeus E. Mey. & Fabaceae & Rumex abyssinicus Jacq. & Polygonaceae \\
\hline Dorsetnia soerensenii Friis & Moraceae & Rungia grandis T. Anders. & Acanthaceae \\
\hline Dracaena afromontana Mildbr. & Dracenaceae & Rytigynia neglecta (Hiern) Robyns & Rubiaceae \\
\hline Dracaena fragrans (L.) Ker-Gawl. & Dracenaceae & Salvia nilotica Juss. ex Jacq. & Lamiaceae \\
\hline Dracaena steudneri Scw.ex Engl. & Dracenaceae & Sapium ellipticum (Krauss) Pax & Euphorbiaceae \\
\hline Drymaria cordata (L.) Schultes & Caryophyllaceae & Satureja abyssinica (Benth.) Briq. & Lamiaceae \\
\hline Drynaria volkensii Hieron & Polypodiaceae & Satureja paradoxa (Vatke) Engl. & Lamiaceae \\
\hline Dyschoriste multicaulis O. Kuntze & Acanthaceae & Scadoxus multiflorus (Martyn) Raf. & Amaryllidaceae \\
\hline Ehertia cymosa Thonn. & Boraginaceae & Scadoxus nutans Friis \& Nordal & Amaryllidaceae \\
\hline Ekebergia capensis Sparrm. & Meliaceae & Schefflera abyssinica Harms & Araliaceae \\
\hline Elaphoglossum deckenii (Kuhn) C.Chr. & Lomariopsidaceae & Schefflera myriantha (Bak.) Drake & Araliaceae \\
\hline Elaphoglossum lastii (Bak.) & Lomariopsidaceae & Selaginella kalbreyeri Bak. & Selaginellaceae \\
\hline Elatostemma monticolum Hook. f. & Urticaceae & Setaria poiretiana (Schult.) Kunth. & Poaceae \\
\hline Embelia schimperi Vatke & Myrsinaceae & Sicyos polyacanthus Cogn. & Cucurbitaceae \\
\hline Engleria woodfordioides Balle. & Loranthaceae & Sida rhombifolia L. & Malvaceae \\
\hline Erythrina brucei Schweinf. & Fabaceae & Smithia elliottii Bak.f. & Fabaceae \\
\hline Erythrococca trichogyne Prain & Euphorbiaceae & Solanum capsicoides Guatteri & Solanaceae \\
\hline Eucalyptus grandis Maiden & Myrtaceae & Solanum dasyphyllum Schum. & Solanaceae \\
\hline Euphorbia ampliphylla Pax & Euphorbiaceae & Spermacoce princeae Verdc.A220 & Rubiaceae \\
\hline Fagaropsis angolensis (Engl.) Dale & Rutaceae & Stellaria sennii Chiov. & Caryophyllaceae \\
\hline Ficus ovata Vahl & Moraceae & Stephania abyssinica (Dill \& A. Rich.) Walp & Menispermaceae \\
\hline Ficus sur Forssk. & Moraceae & Syzygium guineense (Willd.) DC. & Myrtaceae \\
\hline Ficus thonningii Blume & Moraceae & Tagetes minuta $\mathrm{L}$. & Asteraceae \\
\hline Ficus vasta Vahl. & Moraceae & Teclea nobilis Del. & Rutaceae \\
\hline Flacourtia indica (Burm.f.) Merrill & Flacourtiaceae & Tectaria gemmifera (Fee') Alston & Aspidiaceae \\
\hline Galiniera saxifraga (Hochst.) Bridson & Rubiaceae & Thalictrum rhynchocarpum Dill. \& A. Rich & Ranunculaceae \\
\hline Geranium arabicum Forrsk. & Geraniaceae & Thelypteris madagascariensis (Fee') Scelpe & Thelypteridaceae \\
\hline Gouania longispicata Engl. & Rhamnaceae & Tiliacora troupinii Cuf. & Menispermaceae \\
\hline Grevillea robusta Cunn. & Proteaceae & Trichilia dregeana Sond. & Meliaceae \\
\hline Guizotia scabra (Vis.) Chiov. & Asteraceae & Trichomanes melanotrichum Schlecht. & Hymenophyllaceae \\
\hline Helichrysum schimperi Moesner & Asteraceae & Trichomanes pyxidiferum L. & Hymenophyllaceae \\
\hline Heteropogon contortus Roem. \& Schult. & Poaceae & Trifolium usambarense Taub. & Fabaceae \\
\hline Hibiscus berberidifolius A. Rich & Malvaceae & Trilepisium madagascariense DC. & Moraceae \\
\hline Hibiscus calyphyllus Cavan. & Malvaceae & Tristemma mauritianum J. F. Gmel & Melastomataceae \\
\hline Hippocratea goetzei Loes. & Celastraceae & Triumfetta brachyceras K. Schum. & Tiliaceae \\
\hline Hyparrhenia pilgeriana C.E. Hubb. & Poaceae & Vepris dainellii (Pich.-Serm.) Kokwaro & Rutaceae \\
\hline Hypericum peplidifolium A. Rich. & Hypericaceae & Vernonia amygdalina Del. & Asteraceae \\
\hline Hypericum quartinianum A. Rich & Hypericaceae & Vernonia auriculifera Hiern & Asteraceae \\
\hline Hypoestes forskaolii Roem. \& Schult. & Acanthaceae & Vernonia leopoldi Vatke & Asteraceae \\
\hline $\begin{array}{l}\text { Hypoestes triflora (Forssk.) Soland.ex Roem. \& } \\
\text { Schult. }\end{array}$ & Acanthaceae & Viscum angolense De Wild. & Loranthaceae \\
\hline Ilex mitis (L.) Radlk. & Aquifoliaceae & Vittaria guineensis Desv & Vittariaceae \\
\hline Impatiens ethiopica Grey-Wilson & Basalminaceae & Zehneria minutiflora (Cogn.) C. Geffrey & Cucurbitaceae \\
\hline Indigofera atriceps Hook.f. & Fabaceae & & \\
\hline
\end{tabular}

